\title{
THE AMENDMENTS TO THE ALBERTA SECURITIES ACT
}

\section{THOMAS A. SIDES*}

Important changes to Alberta's securities law are now working their way through the legislative process. The author explains what the effects of these proposed amendments will be in the areas of futures trading, investigation and enforcement, reporting of material changes, and exemptions applicable to private placements.
D'importants changements relatifs à la loi des valeurs mobilieres de l'Alberta sont actuellement soumis à un processus législatif. L'auteur explique quelles seront les conséquences des amendements proposés en ce qui touche les opérations a terme, les responsabilités de la commission des valeurs mobilières, les déclarations de changements importants et les exemptions applicables aux placements privés.

\section{TABLE OF CONTENTS}

I. FUTURES TRADING $\ldots \ldots \ldots \ldots \ldots \ldots \ldots \ldots$

II. INVESTIGATION AND ENFORCEMENT

POWERS ENHANCED . . . . . . . . . . . . . . . . . . . 929

III. MATERIAL CHANGES $\ldots \ldots \ldots \ldots \ldots \ldots \ldots \ldots \ldots \ldots \ldots$

IV. PRIVATE PLACEMENT AMENDMENTS $\ldots \ldots \ldots \ldots \ldots \ldots 933$

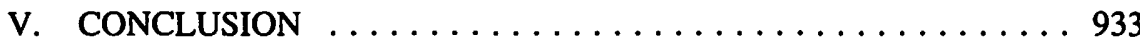

The Securities Amendment Act, 1991, ${ }^{1}$ represents a new initiative ${ }^{2}$ in securities regulation in Alberta by extending the securities regulatory framework to the trading of futures contracts. This act also contains significant amendments that will grant the Alberta Securities Commission (the "Commission") enhanced investigatory and enforcement powers. In addition, it also amends the rules governing private placements and material change reports. The Securities Amendment Act, 1991, when proclaimed in force, will amend the Securities Act. ${ }^{3}$

\section{FUTURES TRADING}

\section{A. INTRODUCTION}

Trading in futures contracts and options is currently unregulated by legislation in Alberta. Commodity futures contracts, one type of futures contract, were not considered to be securities in Ontario until specific legislation was enacted. ${ }^{4}$ It has not been definitively determined in Alberta that a futures contract constitutes a "security". 5 blanket order of the Commission dated May 28, 1987 titled "The Toronto Futures

\section{Barrister and Solicitor, Milner Fenerty, Edmonton.}

Securities Amendment Act, 1991, S.A. 1991, c. 33 received royal assent on June 25, 1991.

Bill 3, The Commodity Futures Act, 1st Sess., 19th Leg. Alta., 1979, did not receive royal assent. This bill proposed regulation of futures trading by a separately constituted board.

3. S.A. 1981, c. S-6.1 (the "Alberta Securities Act").

4. Pacific Coast Coin Exchange v. Ontario Securities Commission, [1978] 2 S.C.R. 112 at 116.

5. Alberta Securities Act, s. 1(v). 
Exchange and the TSE 35 Spot Index Contract and the TSE 35 Index Futures Contract" exempts, on certain conditions, trading in these contracts from the registration and prospectus requirements of the Alberta Securities Act. The granting of this exemption order by the Commission, pursuant to section 116 of the Alberta Securities Act, indicates that the Commission may be of the opinion that trading in these stock index futures contracts arguably constitutes trading in a security. However, this blanket order does not regulate traditional commodity or financial futures contract trading. One may expect that it will be rescinded once the Securities Amendment Act, 1991 is proclaimed in force.

The provinces of British Columbia, Manitoba and Ontario have enacted legislation regulating trading in futures contracts. The futures provisions of the Securities Amendment Act, 1991 are strikingly similar to the corresponding provisions of the British Columbia Securities Amendment Act, $1990^{6}$ which will be integrated into the British Columbia Securities Act ${ }^{7}$ contemporaneously with the repeal of the Commodity Contract Act. ${ }^{8}$ The regulation of futures contract trading under the Alberta Securities Act, utilizing the current infrastructure of the Commission as opposed to regulation under a separate act," represents sensible regulation based upon the common characteristics of futures and securities trading.

\section{B. FUTURES CONTRACTS}

Essentially, a futures contract is an agreement to purchase or sell the underlying interest at a specific price and rate on a specific future date. The principal reason for the development of futures markets, upon which futures contracts are traded, is to provide an efficient and effective mechanism for the management of price risks. The development of futures trading can be understood by examining the users of futures contracts. Users are typically of two types: hedgers and speculators. Hedgers are those who have a position or potential position in the actual commodity concerned, normally as a regular part of their business activity, who either attempt to minimize the price risk on their physical holdings by selling futures contracts or attempt to lock in present prices by buying futures contracts. ${ }^{10}$ Speculators do not often have a position in the underlying commodity and seek to make a profit from anticipated increases or decreases in future prices. Speculators play a crucial role in providing market liquidity, or risk capital, which in turn encourages hedgers to use the market.

Until recently trading in futures contracts centred on underlying interests consisting of agricultural commodities and metals, but now contracts exist for a wide range of financial instruments, such as foreign currency, interest rates, treasury bonds and bills, and stock indexes. The growth in trading of futures contracts has created new opportunities for risk

6. S.B.C. 1990 , c. 25 (the "B.C. Securities Amendment Act, 1990").

7. S.B.C. 1985 , c. 83 (the "B.C. Securities Act").

8. R.S.B.C. 1979 , c. 56.

9. For example, see Ontario's Commodity Futures Act, R.S.O. 1980, c. 78.

10. J.E. Hore, Trading on Canadian Futures Markets, 4th ed. (Toronto: Canadian Securities Institute, 1989). at 7. 
management for diverse industry participants. Since intermediaries involved in futures trading provide trading advice to, and hold the funds of, participants in the market, the Alberta Department of Consumer and Corporate Affairs presumably perceives a need for legislation to regulate the trading activities of these intermediaries.

\section{REGULATION OF FUTURES TRADING}

A "futures contract" is defined in the Securities Amendment Act, 1991 to mean a contract to make delivery or take delivery, on a specified date or during a specified period, of a specified asset or its cash equivalent." A futures contract constitutes a "security" under the amendments. However, if a futures contract is an "exchange contract," it is not regulated as a security. ${ }^{12}$

An "exchange contract " is defined in the Securities Amendment Act, 1991 to mean a futures contract or an option the performance of which is guaranteed by a clearing agency, and which is traded on an exchange pursuant to standardized terms and conditions at a price agreed on when the contract is entered into. Any instrument or class of instruments that meet these requirements may be designated as an exchange contract by an order of the board of the Commission ${ }^{13}$ (the "Board"). The exclusion of exchange contracts from the definition of "security" means that such contracts are not subject to the prospectus requirements of the Alberta Securities Act; instead, disclosure requirements are to be determined by the exchange upon which the contracts are traded. However, in most other respects, exchange contracts are subject to the same regulation as securities.

An exchange must be recognized by the Board under section 52 of the Alberta Securities Act before trading is permitted in an exchange contract. ${ }^{14}$ Currently, the Toronto Futures Exchange, the Montreal Exchange, and the Winnipeg Commodity Exchange are the only futures contract markets in Canada. If a futures contract or an option were introduced for trading on an exchange not recognized by the Board or had not been designated as an exchange contract by an order of the Board, the contract or option would be considered a security. A prospectus would then be required to be cleared by the Commission unless an exemption order was obtained.

An "option" is not defined in the Securities Amendment Act, 1991. It has conventionally been defined to mean a right, but not an obligation, to buy or sell specific securities or properties at a specified price within a specified time. There are two types of options: "calls" and "puts." A call option gives the purchaser the right to buy a certain security or futures contract at a certain price within a certain time period. A put option gives the purchaser the right to sell a certain security or futures contract at a certain price within a certain time. Under the Securities Amendment Act, 1991's regulation of the trading of options, the blanket order of the Commission dated October 25, 1984 titled 
"Recognized Options Cleared Through Recognized Clearing Organizations" will be rescinded.

The provisions of the Securities Amendment Act, 1991 pertaining to exchange contracts and futures contracts closely resemble the corresponding provisions in the B.C. Securities Amendment Act, 1990. It can be anticipated that the regulations to be enacted under the Alberta provisions will be based upon the corresponding regulations to be enacted pursuant to the B.C. Securities Act once the provisions of the B.C. Securities Amendment Act, 1990 pertaining to exchange contracts are proclaimed in force. Among other requirements, these regulations will impose registration requirements upon individuals and corporations trading in exchange contracts as well as establishing proficiency and minimum net free capital requirements for these registrants.

\section{INVESTIGATION AND ENFORCEMENT POWERS ENHANCED}

The amendments contained in the Securities Amendment Act, 1991 enhancing the Commission's investigatory and enforcement powers parallel, in a number of respects, similar provisions recently proposed for the Ontario Securities $A c t^{15}$ and already reflected in the B.C. Securities Act. Certain of these amendments acknowledge the increasing internationalization of securities markets and the necessity of co-operating in conducting investigations across jurisdictional boundaries.

The Chief of Securities Administration, the senior staff member of the Alberta Securities Commission Agency (the "Commission Agency"), is to be given increased powers to conduct an investigation into alleged contraventions of the Alberta Securities Act and the regulations enacted under it (the "Regulations"). Whereas section 18 of the Alberta Securities Act now provides only the Board with the ability to engage the services of an expert to provide advice, the Chief of Securities Administration will have this ability pursuant to the amendments to section $18 .^{16}$

The Chief of Securities Administration will also have the ability to refer any matter to the Board for its consideration; the Board may then conduct a hearing, make an order, or provide advice and direction to the Chief of Securities Administration in respect of the matter referred. ${ }^{17}$ The addition of this referral power may have the effect of reducing the stratification that currently exists between the Board and the Commission Agency. The Chief of Securities Administration will be able to refer any matter including, for example, a determination of the public interest or the interpretation of a section of the Alberta Securities Act to the Board for determination. This will enable the Board to express a view on important issues without the necessity of there being a specific dispute or controversy between Commission Agency staff and a particular person or company. 
The amendments to sections 28(1), 33(1) and $35^{18}$ of the Alberta Securities Act acknowledge that, with the increasing internationalization of securities markets, it will be necessary to appoint persons and release information to such persons and to governments, government agencies or regulatory organizations in order to prosecute violations of securities legislation successfully. Furthermore, the amendments to sections 28(1) and 33(1) clarify the Chief of Securities Administration's and the Minister of Consumer and Corporate Affairs' power to order an investigation and provide an express power to implement memoranda of understanding with other jurisdictions, such as the existing Memorandum of Understanding among the Ontario Securities Commission, the Commission des valeurs mobilieres du Quebec, the British Columbia Securities Commission, and the United States Securities and Exchange Commission.

The Chief of Securities Administration will also be empowered, under the amendments to section 35 , to release information, testimony, records, documents or things obtained under the Alberta Securities Act at any time as long as he considers such release to be in the public interest. Under the existing section 35, he may only release information in respect of an investigation and only at a time prior to the conclusion of an investigation ordered under section 28. The Board will be given the power to make an order, after conducting a hearing, to cause a person to resign as a director or officer of an issuer or that a person be prohibited from becoming or acting as a director or officer. ${ }^{19}$ Similar powers are currently available under the Quebec Securities $A t^{20}$ and the B.C. Securities Act and are contained in proposals to amend the Ontario Securities Act.

In an effort to reduce the costs to the public of conducting an investigation or hearing, and as an additional deterrent to potential offenders, the Board or the Chief of Securities Administration may order a person or company to pay the costs of an investigation or hearing where it is determined that the person or company has not complied with or is guilty of an offence under the Alberta Securities Act or the Regulations. The Chief of Securities Administration may file with the Court of Queen's Bench a certificate stating the amount of the costs that the person or company is required to pay and this filed certificate has the same force and effect as if it were a judgment of the court for the recovery of debt. Therefore the Commission will be able to avail itself of the enforcement mechanisms provided under the Alberta Rules of Court to enforce payment of a judgment.

The Board will also have the ability to file any other decision it makes, after conducting a hearing, with the clerk of the Court of Queen's Bench. ${ }^{21}$ This filed decision will have the same force and effect as if it were a judgment of the court. In addition to providing the Commission with an effective mechanism for the recovery of the payment of a monetary debt owed it, this new provision may eliminate the necessity of the Chief of Securities Administration's applying to the Court of Queen's Bench

18. Ibid. ss. 6, 7 and 8, respectively.

19. Ibid. s. 33 .

20. R.S.Q., c. V-1.1.

21. Securities Amendment Act, 1991, s. 33. 
pursuant to section 164 of the Alberta Securities Act to obtain an order to cause a person or company to comply with the terms of a decision of the Board.

Section 21 of the Alberta Securities Act currently permits the Board or the Chief of Securities Administration to make an interim order without a hearing if, in its or his opinion, the length of time required for a hearing could be prejudicial to the public interest. Under this section, the interim order may be extended until the hearing is concluded only if the hearing is commenced within 15 days from the day on which the interim order is made. The amendment ${ }^{22}$ to section 21 introduces flexibility by enabling the Board or the Chief of Securities Administration to extend an interim order without the necessity of a hearing's having been commenced within a certain time period. This amendment provides that if the Board or the Chief of Securities Administration is of the opinion that it would not be prejudicial to the public interest to do so, it or he may, without conducting a hearing, extend the interim order until a hearing is conducted and a decision is rendered.

Pursuant to Section 167 of the Alberta Securities Act, the limitation period within which proceedings can be commenced begins on the day that the facts upon which the proceedings are based first came to the knowledge of the Chief of Securities Administration. The limitation period in respect of proceedings to be commenced in a court is one year and in respect of proceedings before the Board, two years. The subjective test, namely, "after the facts upon which the proceedings are based first came to the knowledge of the Chief of Securities Administration," has resulted in challenges of the jurisdiction of the court or of the Board on the basis that the limitation period had expired prior to the commencement of proceedings. ${ }^{23}$ The new objective test, which will be easier to apply, and the six-year limitation period contained in the amendments to section $167^{24}$ may lessen such challenges. This limitation period will not apply to statutory causes of action presently subject to shorter limitation periods, such as an action for rescission under section 175 of the Alberta Securities Act.

The new offence of market manipulation will become section 70.1 of the Alberta Securities Act. ${ }^{25}$ This section states:

70.1 No person or company shall, directly or indirectly, trade in or purchase a security or an exchange contract if the person or company knows or ought reasonably to know that the trade or purchase

(a) creates or may result in a false or misleading appearance of trading activity in a security or an exchange contract, or

22. Ibid. s. 5.

23. Section 25 of the Ontario Securities Act contains the same subjective test as section 167 of the Alberta Securities Act and the types of challenges of commission or court proceedings are illustrated in the following reported Ontario Securities Commission decisions: Crowe v. Sheridan, June 1967 O.S.C.B. 6; W.D. Latimer Co., 1975 O.S.C.B. 103; and R. v. Watling, November 1964 O.S.C.B. 2.

24. Securities Amendment Act, 1991, s. 34.

2s. Ibid. s. 22. 
(b)

creates or may result in an artificial price for a security or an exchange contract.

Section $196(\mathrm{~s} .4)^{26}$ allows for regulations to be enacted that will determine, for the purposes of section 70.1, what constitutes a false or misleading appearance of trading activity or an artificial price. The introduction of this new offence may alleviate the difficulty that has been encountered in proving the intent necessary for a conviction for securities-related offences under the Canadian Criminal Code. ${ }^{27}$

\section{MATERIAL CHANGES}

Those who are familiar with the material change provisions of the Ontario Securities Act will recognize the changes implemented for the corresponding sections of the Alberta Securities Act by the Securities Amendment Act, 1991. The ambit of the definition of "material change," contained in section 1(k.1) of the Alberta Securities Act, will be broadened by the recent amendments. A material change report will have to be filed with the Chief of Securities Administration pursuant to the Regulations if senior management of the issuer believe that confirmation of a decision to implement a material change by the board of directors of the issuer is probable. ${ }^{28}$ This amendment will mean that a material change will be reportable on an earlier basis than that currently required, which is the time of the decision by the board of directors to implement the change.

The amendments to section 118 of the Alberta Securities Act relate primarily to a claim for confidentiality in respect of a filed material change report. Currently, under section 118(3), if in the opinion of the reporting issuer preparing, filing, and publishing a notice of material change within ten days from the day on which the change occurs would be unduly detrimental to its affairs, it may keep the change confidential until publication is no longer unduly detrimental. Under this requirement, a reporting issuer is able to determine subjectively whether or not publication would be unduly detrimental to its affairs subject only to the "sunset" provision contained in section 118(4) requiring eventual publication. This provision, unaltered by the proposed amendments, provides that in any event a material change report must be filed, issued and published not later than 180 days from the day that the material change became known to the reporting issuer, subject to the authority of the Chief of Securities Administration to shorten the 180-day period.

The reporting issuer claiming confidentiality in respect of a material change must, under the amendments to section 118, file the material change report with the Chief of Securities Administration on a confidential basis together with written reasons for the nondisclosure if, in the opinion of the reporting issuer, the disclosure requirements would be unduly detrimental to the reporting issuer's affairs, or the material change consists of a decision made by the senior management of the reporting issuer, the senior management believes that confirmation of that decision by the board of directors is probable, and it has

26. Ibid. s. 38(h).

27. R.S.C. 1985 , c. C-46. See section 380 (2) and sections 382 to 384 of the Canadian Criminal Code.

28. Securities Amendment Act, 1991, s. 2(f). 
no reason to believe that any person with knowledge of the material change has made use of that knowledge in purchasing or selling securities of the reporting issuer. ${ }^{29}$ Presumably these added requirements will allow the Chief of Securities Administration the opportunity to assess, and perhaps question, the validity of a claim for confidentiality. The reporting issuer will also be required to advise the Chief of Securities Administration in writing, within ten days from the day of filing the initial material change report on a confidential basis and within every ten-day period thereafter, that it believes the report should continue to remain confidential until the material is generally disclosed in accordance with the prescribed disclosure requirements, or a decision to implement a change made by senior management of the reporting issuer is rejected by its board of directors. ${ }^{30}$

\section{PRIVATE PLACEMENT AMENDMENTS}

The references to monetary amounts and number of purchasers governing the registration and prospectus exemptions applicable to private placements are proposed to be removed from the Alberta Securities Act in order that they may be prescribed by regulation. For example, the $\$ 97,000$ acquisition cost exemption contained in sections 65(1)(e) and 107(1)(d) of the Alberta Securities Act will be changed to an amount prescribed by regulation. Presumably, this amount will initially be set at $\$ 150,000$, currently the minimum acquisition cost contained in the corresponding Ontario regulations. The apparent rationale for removing the specific figures from the Act is to provide a measure of flexibility in the face of a changing financial marketplace, since legislative amendments are more cumbersome and slow than amendments to the Regulations.

\section{CONCLUSION}

The proclamation of the Securities Amendment Act, 1991 will bring the Alberta Securities Act into line with recent amendments or proposed amendments to the securities legislation of British Columbia, Ontario and Quebec. The beefed-up investigation and enforcement powers will provide the Commission with increased flexibility to regulate the securities industry in Alberta in a manner that provides effective protection to the investing public while maintaining the integrity of the capital markets. The amendments will also allow the Commission to fulfil its mandate by ensuring that investigations may be conducted on an interjurisdictional basis. Finally, the regulation of futures trading will require those persons or companies engaged in such trading in Alberta to be cognizant of and to be prepared to conduct their trading activities in accordance with the legislative regime governing securities trading in general. 